\title{
In Memoriam: Ronald E. Bedford (26 June 1930-3 November 2020)
}

Ron Bedford, active member of the Ottawa FieldNaturalists' Club (OFNC) and Honorary Member (since 2010; OFNC 2011), died in Ottawa, at age 90 (Ottawa Citizen 2020). He was a distinguished scientist at the National Research Council of Canada, in Ottawa for 40 years before retiring in 1995. He earned his Ph.D. in physics in 1955 from the University of British Columbia. He also served on the OFNC Publications Committee for 32 years, including as Chair. A full tribute is planned for an upcoming issue of The Canadian Field-Naturalist.

\section{Literature Cited}

OFNC (Ottawa Field-Naturalists' Club). 2011. Ronald E. Bedford - 2010 Honorary Member. Accessed 4 February 2021. https:/ofnc.ca/wp-content/uploads/2017/09/2010 HonoraryMember_RonBedford.pdf.

Ottawa Citizen. 2020. Obituary: Bedford, Ronald Ernest June 26, 1930 - November 3, 2020. Accessed 4 February 2021. https://ottawacitizenremembering.ca/obituary/ ronald-bedford-1080816364.

D.A.W. LEPITZKI

CFN Editor-in-Chief

(C) The author. This work is freely available under the Creative Commons Attribution 4.0 International license (CC BY 4.0). 